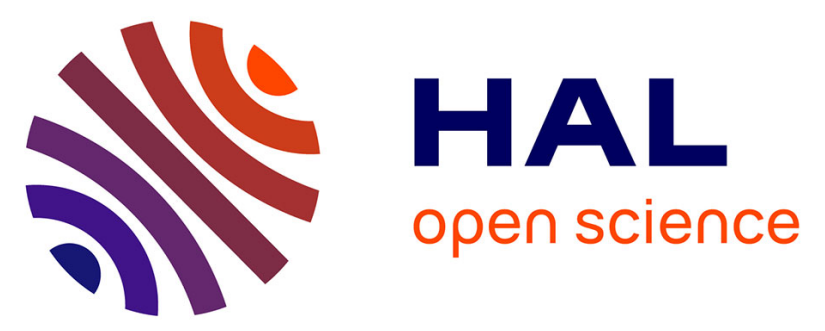

\title{
Population structure enhances perspectives on regional management of the western Indian Ocean green turtle
}

Jérôme Bourjea, Jeanne A. Mortimer, Julie Garnier, Gladys Okemwa, Brendan J. Godley, George Hughes, Mayeul Dalleau, Claire Jean, Stéphane Ciccione, Delphine Muths

\section{To cite this version:}

Jérôme Bourjea, Jeanne A. Mortimer, Julie Garnier, Gladys Okemwa, Brendan J. Godley, et al.. Population structure enhances perspectives on regional management of the western Indian Ocean green turtle. Conservation Genetics, 2015, 16 (5), pp.1069-1083. 10.1007/s10592-015-0723-3 . hal01306706

\section{HAL Id: hal-01306706 \\ https: / hal.univ-reunion.fr/hal-01306706}

Submitted on 26 Apr 2016

HAL is a multi-disciplinary open access archive for the deposit and dissemination of scientific research documents, whether they are published or not. The documents may come from teaching and research institutions in France or abroad, or from public or private research centers.
L'archive ouverte pluridisciplinaire HAL, est destinée au dépôt et à la diffusion de documents scientifiques de niveau recherche, publiés ou non, émanant des établissements d'enseignement et de recherche français ou étrangers, des laboratoires publics ou privés. 


\title{
Population structure enhances perspectives on regional management of the western Indian Ocean green turtle
}

\author{
Jérôme Bourjea $^{1,8} \cdot$ Jeanne A. Mortimer $^{2,10,11,12} \cdot$ Julie Garnier $^{3} \cdot$ Gladys Okemwa $^{4,9}$. \\ Brendan J. Godley $^{5} \cdot$ George Hughes $^{6} \cdot$ Mayeul Dalleau $^{7}$ - Claire Jean ${ }^{7}$. \\ Stéphane Ciccione ${ }^{7} \cdot$ Delphine Muths ${ }^{1}$
}

\begin{abstract}
To refine our understanding of the spatial structure of the green turtle (Chelonia mydas) populations in the South West Indian Ocean (SWIO), we analysed patterns of mitochondrial DNA (396 base pairs control region fragment) variation among 171 samples collected at five distinct locations (Kenya, Northern Mozambique, and three locations in the Republic of Seychelles: the Granitic, Amirantes, and Farquhar groups) and compared them to genetic data $(n=288)$, previously collected from 10 southern locations in the SWIO. We also analysed postnesting satellite tracks $(n=4)$ from green turtles nesting in the Amirantes group. Pairwise comparisons of haplotype frequencies showed significant genetic differentiation amongst rookeries and suggest that the SWIO hosts two
\end{abstract}

Jérôme Bourjea

jbourjea@ifremer.fr; jerome.bourjea@ifremer.fr

1 Institut Français de Recherche pour l'Exploitation de la Mer, Ifremer, Délégation de La Réunion, Rue Jean Bertho, BP 60, 97822 Le Port Cedex, Ile de La Réunion, France

2 Department of Biology, University of Florida, Gainesville, FL, USA

3 The Zoological Society of London, Regent's Park, London NW1 4RY, UK

4 Kenya Sea Turtle Conservation Committee (KESCOM), P.O. Box 84688, Mombasa 80100, Kenya

5 Marine Turtle Research Group, Centre for Ecology and Conservation, University of Exeter, Penryn Campus, Treliever Road, Penryn, Cornwall TR10 9EZ, UK

6183 Amber Valley, Private Bag X30, Howick 3290, South Africa main genetic stocks of nesting green turtles that could themselves be divided in two sub-stocks that still need to be confirmed: A. the Southern Mozambique Channel, that could be composed of two sub-stocks (a1) Europa and (a2) Juan de Nova, and B. the Northern SWIO (N-SWIO) comprising two sub-stocks (b1) the Seychelles archipelago stock-SEY; and (b2) the remaining Northern SWIO rookeries. The newly revealed differentiation of the Seychelles population is supported by restricted migration of females tracked from the Amirantes group suggesting relatively limited links with other regional stocks. We hypothesize that this differentiation could be due to local and regional current patterns and to the role of the IndoPacific Barrier as a genetic break, enhanced during periods of sea level decrease associated with a rare but continuous flow of hatchlings and young juveniles from Western Australia.

7 KELONIA, l'observatoire des tortues marines de La Réunion, 46 rue du Général De Gaulle, 97436 Saint Leu, La Réunion, France

8 University of Reunion Island, FRE3560 INEE-CNRS, 15 Avenue René Cassin, BP 7151, 97715 Saint Denis, La Reunion, France

9 Kenya Marine and Fisheries Research Institute, P.O. Box 81651-80100, Mombasa, Kenya

10 P.O. Box 1443, Victoria, Mahé, Seychelles

11 Save Our Seas Foundation D'Arros Research Centre, D'Arros Island, Seychelles

12 Island Conservation Society, P.O. Box 775, Victoria, Mahé, Seychelles 
Keywords Indian Ocean - mtDNA - Satellite tracking Phylogeography · Management unit · Chelonia mydas

\section{Introduction}

Populations of many large animal species have been severely depleted over the last century (Malakoff 1997). One of the primary challenges for conservation of widely distributed, long-lived taxa includes assessing status at biologically appropriate scales in order to define conservation priorities. Genetic studies constitute an efficient means to determine effective dispersal and to delineate stock boundaries (Palumbi 2003). Population genetic analyses have much to offer in unlocking the secrets of the ecology of migratory species, especially in the provision of tools enabling unequivocal species identification, assessment of stock structure and their connectivity (Avise 1998). Such techniques have already proven to be effective in fisheries management, despite many marine fishes having long larval periods allowing widespread dispersal in currents and long-lived adults, in some cases, being migratory, further increasing levels of gene flow (Ward 2000). For example, whereas all tuna species are highly migratory, genetic differentiation has been detected at various scales, within an ocean basin for bluefin tuna (Carlsson et al. 2004), and both within and among oceans for yellowfin tuna (Ely et al. 2005) and bigeye tuna (Alvarado Bremer et al. 1998; Durand et al. 2005). In the case of threatened species, where decisions about management are both difficult and central to species survival, it becomes apparent that information on the genetic differences among populations are important for adequate management (DeSalle and Amato 2004). The identification of management units (MUs), defined here as populations of conspecific individuals among which the degree of connectivity is sufficiently low so that each population should be monitored and managed separately (Taylor and Dizon 1999), is central to the short-term management and conservation of natural populations (Schwartz et al. 2007).

Marine turtles have been subject to centuries of direct exploitation (Parsons 1962) and therefore are considered species of conservation concern (The IUCN Red List of Threatened Species www.iucnredlist.org; accessed on 19 August 2014). Due to the difficulty of accessing individuals in their marine habitats which can be distributed over thousands of kilometers, knowledge of population dynamics at a regional scale has, until recently, been derived from long-term mark-recapture studies of females flipper tagged while nesting (e.g. Read et al. 2014) or tracked using satellite telemetry (e.g. Hawkes et al. 2012). Subsequently, genetics have shown that due to the philopatric behaviour of females (Meylan et al. 1990), marine turtle populations tend to be structured along female lineages and numerous studies have successfully used mtDNA frequencies to resolve population boundaries among breeding green turtle sites separated by more than $150 \mathrm{~km}$. This includes those in the Atlantic and Mediterranean (e.g. Encalada et al. 1996; Reece et al. 2005), in the Pacific (e.g. Dethmers et al. 2006; Hamabata et al. 2014, Dutton et al. 2014a, b) and the Indian Ocean (e.g. Bourjea et al. 2007b). The results of these studies made it possible to define discrete MU, i.e. a population functionally independent, that can be characterized using various tools or indicators, such as genetic markers, life history traits, behavior (Moritz 1994) and to develop regional management unitsRMU for marine turtle conservation that spatially integrate sufficient information to account for complexities in marine turtle population structures (Wallace et al. 2010; 2011).

The South West Indian Ocean (SWIO) is defined here as the waters bounded by the eastern coast of Africa between Kenya and South Africa eastward to $74^{\circ} \mathrm{E}$, and from $1^{\circ} \mathrm{S}$ in the North to $30^{\circ} \mathrm{S}$ in the south. This region hosts some of the most important nesting and feeding grounds for green turtles (Hughes 1973; Frazier 1975; Mortimer 1984; Le Gall et al. 1986; Le Gall 1988) and includes major green turtle nesting areas, especially on isolated islands (Frazier 1984; Mortimer 1984, 1985, 1988; Le Gall 1988; Mortimer and Day 1999; Bourjea et al. 2007a; Lauret-Stepler et al. 2007; Mortimer et al. 2011a, b) that host thousands of females, annually (see review in Dalleau et al. 2012). Nesting of green turtles also occurs on the African mainland and islands of the east African coast, from central Mozambique to Kenya (Frazier 1975, 1984; Howell and Mbindo 1996; Hughes 1996; Okemwa et al. 2004; Garnier et al. 2012;). However, in Mozambique, Tanzania and Kenya, the status of marine turtles is still somewhat poorly known (Bourjea et al. 2009). Based on available data on green turtles in this region, the SWIO was recognized as a single RMU in the Indian Ocean (Wallace et al. 2011) but there is a paucity of knowledge of how discrete this is from other RMUs in the region, as well as the one in the south Atlantic.

The mtDNA phylogeography for marine turtles shows a rank-order relationship between thermal preference and evolutionary exchange between the Atlantic and the IndoPacific Oceans (Bowen and Karl 2007), with an ancient separation $(\mathrm{d}=4.4 \%$ in control region sequences; Encalada et al. 1996). However, in the specific case of the SWIO, recent leakage of an mtDNA lineage from the Atlantic into the Indian Ocean has been demonstrated (Bourjea et al. 2007b). These authors also found compelling genetic evidence that green turtles nesting on the rookeries of the Southern Mozambique Channel (SMC) and those nesting in the Northern Mozambique Channel (NMC) belong to separate genetic populations (called here genetic stocks). 
The present study examines the mtDNA control region polymorphism variation in the SWIO, integrating 15 previously unsampled sites from five distinct locations: Mozambique, Kenya and three locations in the Republic of Seychelles (Granitic, Amirantes and Farquhar groups). We set out to assess any linkages between the known stocks in the Mozambique Channel, the East African coast and the Seychelles islands. We also examine the post nesting migration from individuals tracked by satellite from the Amirantes. The aim was then to (i) define groups of rookeries that comprise discrete genetic populations, (ii) investigate the patterns of subdivision of rookeries in this region and (iii) discuss the results from a global conservation perspective.

\section{Materials and methods}

\section{Sampling}

Green turtle tissue samples were obtained from 15 sites in the SWIO (Fig. 1, supplemental material Appendix A). In Kenya nesting green turtles were sampled using standard protocols (Dutton 1996) between 2003 and 2006 within a five kilometer sampling site centred on Watamu and Mida Creek, part of the Malindi and Watamu National Marine Parks and Reserves Complex. In Mozambique, samples were collected at Vamizi Island (northern Mozambique, Fig. 1; Garnier et al. 2012) during the breeding seasons 2004-2007 using either clean sharp knives (sampling dead turtles), or a $6 \mathrm{~mm}$ biopsy punch (on live turtles). In Seychelles, samples were collected from three locations including the Granitic, Amirantes and Farquhar groups. All samples were collected either from tagged nesting females, dead nesting females or with due care from dead embryos taking only one sample per clutch and only one per female to avoid duplication of the same matrilineage (supplemental material Appendix A), and using scalpels. Samples were stored in $20 \%$ dimethyl sulfoxide buffer saturated salt solution (Dutton 1996) and frozen until DNA extraction.

Although it is now accepted that female green turtles return to nest on their natal beaches, the geographic specificity of homing is uncertain (Bowen and Karl 2007; Lee 2008). Given that the mtDNA control region marker used on green turtles has failed to identify genetic structure among sites separated by less than $150 \mathrm{~km}$ (reviewed in Bowen and Karl 2007), small sample sizes from islands closer than $150 \mathrm{~km}$ (Fig. 1) and displaying similar biogeographic context were directly pooled for analysis to represent five distinct regions: Kenya, Mozambique and three regions in the Seychelles (Granitic, Amirantes, and Farquhar island groups; Table 1; supplemental material Appendix A).

\section{Genetic analysis}

The same protocols detailed in Bourjea et al. (2007b) were used to extract DNA from small amounts of tissue $(0.1 \mathrm{~g})$ A portion (396 bp) of the mtDNA control region was amplified by PCR (see Bourjea et al. 2007b for detailed protocol) using TCR-5 (5'-TGTACATTACTTATTTACCAC-3') and TRC6 (5'-GTACGTACAAGTAAAATACCGTATGCC-3') primers (Norman et al. 1994). To improve the regional overview of the genetic structure of nesting green turtle in the SWIO, our novel data set was combined with those analysed by Bourjea et al. (2007b; Fig. 1; Table 1). For Farquhar, we combined the samples presented in this study $(n=20)$ with the previous ones $(n=7)$, for a total of 27 samples. We refer in this paper to the SMC as the area including Europa and Juan de Nova, and the Northern South West Indian Ocean (N-SWIO) as all the other our study sites (Table 1).

Haplotype nomenclature of newly identified haplotypes follows that reported by the Southwest Fisheries Science Center (http://swfsc.noaa.gov/prd-turtles.aspx) for the 384 bp fragment with Pacific and Indian Ocean haplotypes being assigned a CmP prefix (Dutton et al. 2008). Sequence alignments were performed with the software DNAMAN V.5.2.2 (@Lynnon BioSoft.) and neighbour-joining trees, based on Kimura 2 parameter distance (Kimura 1980), were constructed using Mega 4 software (Kumar et al. 2001).

Haplotype $(h)$ and nucleotide diversity $(\pi)$ were calculated for each rookery using Arlequin V.3.5.1. (Excoffier and Lischer 2010). Pairwise comparison of rookeries was assessed with Wright's fixation index $\mathrm{F}_{\mathrm{ST}}(10,100$ replicates; Wright 1951) estimated by $\theta$ (Weir and Cockerham 1984) and exact tests of population differentiation (Markov chain length: 100,000 steps; Raymond and Rousset 1995) also under Arlequin. The exact test was used here in complement to the conventional $\mathrm{F}$ statistic approach as it may lead to a more accurate and unbiased test for population differentiation composed of small samples and low-frequency haplotypes (Raymond and Rousset 1994). Arlequin was also used for analysis of molecular variance (AMOVA; Excoffier et al. 1992) to determine the a priori partitioning of variation within and among rookeries. Spatial Analysis of Molecular Variance (SAMOVA) software (Dupanloup et al. 2002), that takes into account the geographical location of rookeries and the genetic diversity within and among populations to define the best $\mathrm{K}$ groups that are geographically homogenous and maximally differentiated from each other.

In order to visualise the regional structure of nesting green turtles in the SWIO, haplogroup frequencies (i.e. clades) were used to construct isofrequency maps using inverse distance weighted (IDW) interpolation (Watson 


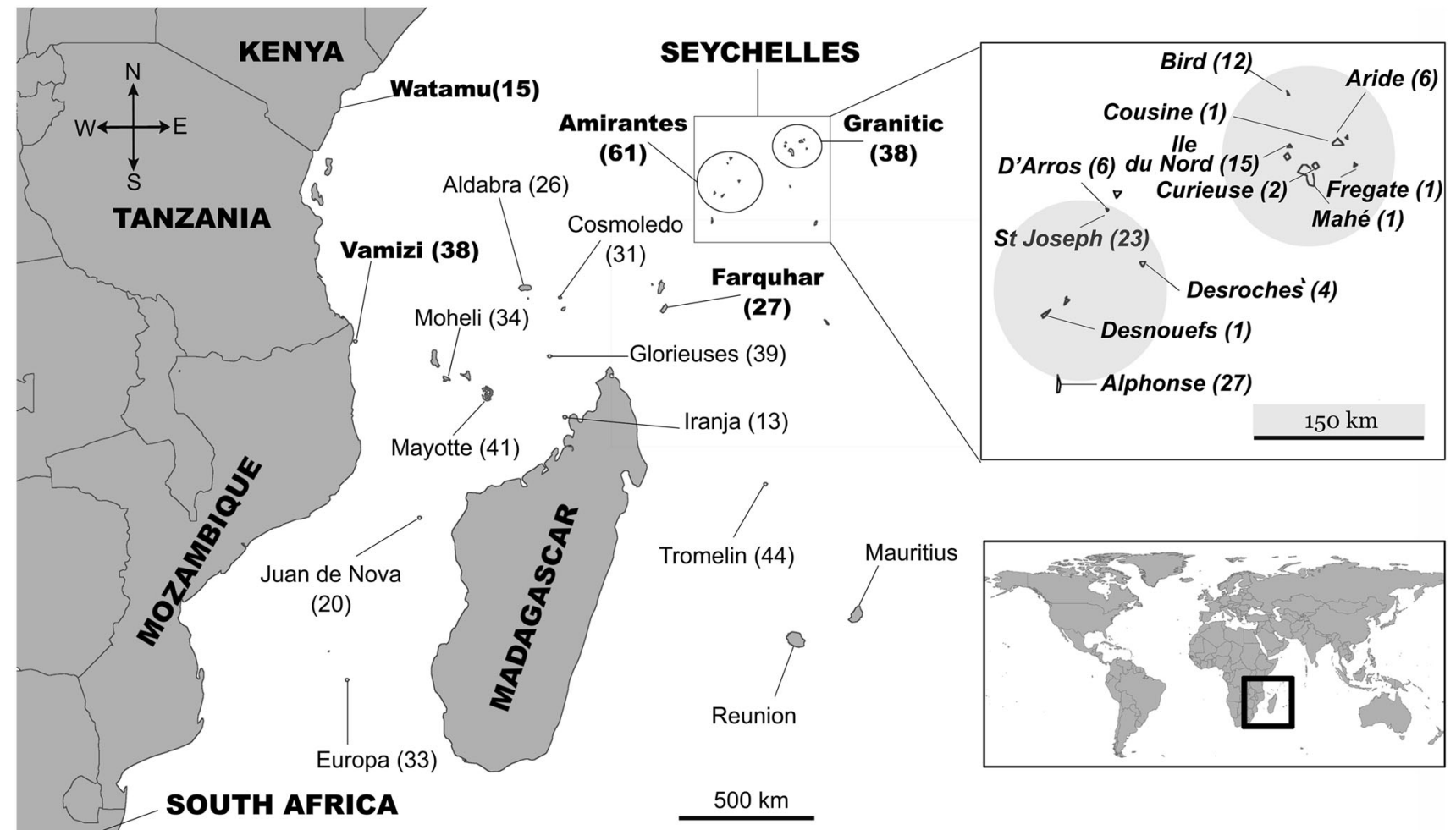

Fig. 1 Geographic locations of the 15 green turtle nesting sites sampled in the South West Indian Ocean. The five new sampled locations are shown in bold italic font. The nine previously sampled

and Philips 1985) in ArcGis 10.1. IDW is a deterministic spatial interpolation model that allows interpolation of spatial data and produces visually appealing contour and surface plots from irregularly spaced data and demonstrates expression trends suggested by the data set. This method is simpler than other interpolation methods as it does not require pre-modeling or subjective assumptions in selecting a semi-variogram model (Henley 1981).

\section{Satellite tracking}

Four adult female green turtles nesting at St. Joseph Island, Amirantes, $\left(5^{\circ} 26^{\prime} \mathrm{S}-53^{\circ} 22^{\prime} \mathrm{E}\right)$ were fitted with satellite transmitters (two TAM-2639-Telonics, Inc., Mesa, Arizona; two SPOT-5-Wildlife Computers, Inc., Bellevue, Washington) in July and September 2012 (supplemental material Appendix B). Transmitters were attached to the carapace of the turtles with epoxy resin Pure2 k (Powers Fasteners Inc., Wieringerwerf, The Netherlands). All transmitters were programmed to transmit data continuously via the Argos satellite system (CLS 2014). Location data were filtered following a classic ad hoc heuristic pre-filtering approach consisting of removing 0 and $\mathrm{Z}$ class locations, on-ground locations and locations involving a speed exceeding $10 \mathrm{~km} \mathrm{~h}^{-1}$. Post-nesting sites are shown in regular font (Bourjea et al. 2007b). Numbers of samples per locality are shown in brackets

migration phases were discriminated by considering temporal patterns of displacement. The start of the migration corresponds to the first date with displacement exceeding $1 \mathrm{~km}$ day $^{-1}$. The end of the migration is considered to be the first date after displacement did not exceed $1 \mathrm{~km}^{\text {day }}{ }^{-1}$ for at least 15 days. Migration paths were smoothed using cubic smooth spline. Foraging area locations were deduced as the centre of all locations post-migration.

\section{Results}

\section{Genetic diversity}

A total of 171 tissue samples were obtained from 15 new sampling sites and these were pooled to represent five nesting locations in the SWIO: Mozambique, Kenya, and Granitic, Amirantes and Farquhar (Table 1). Sequence analysis of the 171 samples revealed 41 variable positions defining 12 different haplotypes, 10 of which had been previously described (Table 1; supplemental material Appendix C).

Haplotype $\mathrm{C} 3$ is by far the most common in all 5 nesting areas occurring in $66.8 \%$ of the samples, followed by A2 (17.6\%) and $\mathrm{Cm} 8$ (3.7. \%). Cm8 was found in Northern 
Table 1 Mitochondrial DNA variants distribution among green turtle populations nesting at 5 newly sampled locations in the South West Indian Ocean (no shading) and in 10 previously analysed locations (grey shading, Bourjea et al. 2007b)

\begin{tabular}{|c|c|c|c|c|c|c|c|c|c|c|c|c|c|c|}
\hline \multicolumn{2}{|c|}{ Main genetic stock } & \multicolumn{3}{|c|}{ Location } & $\mathrm{Cm} 8$ & C3 & $\mathrm{C} 4$ & C5 & IND3 & D2 & Glo33 & A1 & A2 & $\mathrm{CmP} 114$ \\
\hline \multirow{6}{*}{\multicolumn{2}{|c|}{ N - SWIO }} & \multicolumn{3}{|c|}{ Mozambique } & 6 & 28 & 1 & 0 & 1 & 0 & 0 & 0 & 2 & 0 \\
\hline & & \multicolumn{3}{|c|}{ Granitics group } & 0 & 25 & 0 & 0 & 5 & 0 & 0 & 0 & 7 & 0 \\
\hline & & \multicolumn{3}{|c|}{ Amirantes group } & 0 & 33 & 1 & 0 & 1 & 0 & 0 & 2 & 18 & 1 \\
\hline & & \multicolumn{3}{|c|}{ Kenya } & 1 & 13 & 0 & 0 & 0 & 0 & 0 & 0 & 0 & 0 \\
\hline & & \multicolumn{3}{|c|}{ Farquhar } & 0 & 18 & 0 & 1 & 0 & 0 & 0 & 2 & 6 & 0 \\
\hline & & \multicolumn{3}{|c|}{ Total } & 7 & 117 & 2 & 1 & 7 & 0 & 0 & 4 & 33 & 1 \\
\hline \multirow{2}{*}{\multicolumn{2}{|c|}{ SMC }} & \multicolumn{3}{|c|}{ Europa } & 31 & 2 & 0 & 0 & 0 & 0 & 0 & 0 & 0 & 0 \\
\hline & & \multicolumn{3}{|c|}{ Juan de Nova } & 11 & 8 & 0 & 0 & 0 & 0 & 0 & 0 & 1 & 0 \\
\hline \multirow[t]{9}{*}{ N - SWIO } & & \multicolumn{3}{|l|}{ Iranja } & 0 & 13 & 0 & 0 & 0 & 0 & 0 & 0 & 0 & 0 \\
\hline & & \multicolumn{3}{|c|}{ Mayotte } & 5 & 30 & 0 & 0 & 2 & 0 & 0 & 1 & 3 & 0 \\
\hline & & \multicolumn{3}{|c|}{ Mohéli } & 1 & 27 & 0 & 0 & 2 & 1 & 0 & 1 & 2 & 0 \\
\hline & & \multicolumn{3}{|c|}{ Glorieuse } & 0 & 31 & 0 & 0 & 0 & 0 & 1 & 0 & 7 & 0 \\
\hline & & \multicolumn{3}{|c|}{ Cosmoledo } & 0 & 24 & 0 & 0 & 0 & 0 & 0 & 3 & 4 & 0 \\
\hline & & \multicolumn{3}{|c|}{ Aldabra } & 0 & 18 & 0 & 0 & 0 & 0 & 0 & 1 & 7 & 0 \\
\hline & & \multicolumn{3}{|c|}{ Tromelin } & 0 & 38 & 0 & 0 & 0 & 0 & 0 & 0 & 6 & 0 \\
\hline & & \multirow{2}{*}{\multicolumn{3}{|c|}{ Over all populations }} & 55 & 308 & 2 & 1 & 11 & 1 & 1 & 10 & 63 & 1 \\
\hline & & & & & 0 & 118 & 1 & 1 & 6 & 0 & 0 & 8 & 42 & 1 \\
\hline \multirow{2}{*}{$\begin{array}{l}\text { Main genetic } \\
\text { stock }\end{array}$} & \multirow[t]{2}{*}{ Loca } & & $\mathrm{CmP} 115$ & G4 & $\mathrm{CmI} 7$ & $\mathrm{CmP} 152.1$ & Total & Hap & ype & Nuc & tide & Clade & frequenci & ies $(\%)$ \\
\hline & & & & & & & & aive & & dive & & $\begin{array}{l}\text { Clade } \\
1\end{array}$ & $\begin{array}{l}\text { Clade } \\
2\end{array}$ & $\begin{array}{l}\text { Clade } \\
3\end{array}$ \\
\hline N - SWIO & $\mathrm{Mo}$ & bique & 0 & 0 & 0 & 0 & 38 & 0.43 & & 0.02 & & 16 & 79 & 5 \\
\hline & $\begin{array}{r}\text { Gra } \\
\text { gr }\end{array}$ & & 0 & 1 & 0 & 0 & 38 & 0.52 & & 0.01 & & 0 & 82 & 18 \\
\hline & $\begin{array}{r}\mathrm{Am} \\
\mathrm{gr}\end{array}$ & & 1 & 2 & 1 & 1 & 61 & 0.62 & & 0.02 & & 0 & 62 & 38 \\
\hline & Ken & & 0 & 0 & 0 & 0 & 14 & 0.14 & & 0.00 & & 7 & 93 & 0 \\
\hline & Farc & & 0 & 0 & 0 & 0 & 27 & 0.51 & & 0.02 & & 0 & 70 & 30 \\
\hline & Tot: & & 1 & 3 & 1 & 1 & 178 & 0.53 & & 0.02 & & 4 & 74 & 22 \\
\hline SMC & Eur & & 0 & 0 & 0 & 0 & 33 & 0.11 & & 0.00 & & 94 & 6 & 0 \\
\hline & Juar & Nova & 0 & 0 & 0 & 0 & 20 & 0.56 & & 0.03 & & 55 & 40 & 5 \\
\hline N - SWIO & Iran & & 0 & 0 & 0 & 0 & 13 & 0 & & 0 & & 0 & 100 & 0 \\
\hline & Mas & & 0 & 0 & 0 & 0 & 41 & 0.45 & & 0.02 & & 12 & 78 & 10 \\
\hline & Mol & & 0 & 0 & 0 & 0 & 34 & 0.37 & & 0.01 & & 3 & 88 & 9 \\
\hline & Glo & & 0 & 0 & 0 & 0 & 39 & 0.34 & & 0.01 & & 0 & 82 & 18 \\
\hline & Cos & ledo & 0 & 0 & 0 & 0 & 31 & 0.38 & & 0.02 & & 0 & 77 & 23 \\
\hline & Ald & & 0 & 0 & 0 & 0 & 26 & 0.46 & & 0.02 & & 0 & 69 & 31 \\
\hline & Tro & & 0 & 0 & 0 & 0 & 44 & 0.24 & & 0.01 & & 0 & 86 & 14 \\
\hline & $\begin{array}{r}\text { Ove } \\
\text { po }\end{array}$ & ll ations & 1 & 3 & 1 & 1 & 459 & 0.51 & & 0.02 & & 12 & 71 & 17 \\
\hline & & & 1 & 3 & 1 & 1 & 183 & & & & & & & \\
\hline
\end{tabular}

Main genetic stock: N-SWIO = Northern South West Indian Ocean; SMC = South Mozambique Channel. Haplotype diversity $(h)$ and $(\pi)$ nucleotide diversity. Note that Farquhar samples size was increased from $\mathrm{n}=7$ (Bourjea et al. 2007b) to $\mathrm{n}=27$ (present study). Clade 1 is composed of Cm8 haplotype frequency, Clade 2 is composed of C3, C4, C5, D2, Glo33, G4, Cmp152.1 and IND3 haplotypes and Clade 3 is composed of A1, A2, CmI7, CMP114 and CMP115 haplotypes 
Mozambique $(15.8 \%)$, Kenya $(7.1 \%)$ but not in the Seychelles groups. All remaining haplotypes were observed in less than 3 individuals (Table 1). Haplotype diversity $(h)$ was highly variable, ranging from 0.143 for Kenya to 0.617 for the Amirantes group with a high average nucleotide diversity $(\pi=0.023, \mathrm{SD}=0.007)$ and was comparable to that previously found in this region (Bourjea et al. 2007b; Table 1).

When these results were pooled with data from Bourjea et al. (2007b) there was an addition of two other haplotypes: Glo33 and D2 (Table 1; supplemental material Appendix C). The neighbour-joining tree constructed with the 14 haplotypes (Fig. 2) clearly splits the haplotypes into 3 clades (bootstrap value $>0.99$ ). The three Clades are separated by 5.2-6.8 \% mean sequence divergence (Fig. 2) while within-clade divergence was very low (around $0.5 \%)$. The neighbour-joining tree also shows that the two new haplotypes (CMP114 and CMP115; Table 1; supplemental material Appendix C) found in Amirantes group (Seychelles) are part of Clade 3 (composed of A1, A2 and CmI7), CMP115 being distinguished from $\mathrm{A} 2$ by one substitution and CMP114 by two. Clade 1 is composed of CM8 alone and Clade 2 of C3, C4, C5, D2, G4, IND3, Glo33, CmP152.1 haplotypes.

\section{Population genetic structure}

Population differentiation was estimated using $\mathrm{F}_{\mathrm{ST}}$ and exact test based on haplotype frequencies between all the sites sampled in the SWIO (see supplemental material Appendix D for results site by site). The results show that the newly sampled locations in the Seychelles (Granitic,
Amirantes, and Farquhar groups), Kenya, and Mozambique are significantly different from the known SMC Europa $\left(\mathrm{F}_{\mathrm{ST}}=0.670-0.857 ; \mathrm{p}<0.001\right)$ and Juan de Nova stocks $\left(\mathrm{F}_{\mathrm{ST}}=0.244-0.427 ; \mathrm{p}<0.001\right)$. The east African coast locations (Kenya and Mozambique) also show some differences in both F Statistics and exact test from the Seychelles locations but no differentiation from the other N-SWIO locations $\left(\mathrm{F}_{\mathrm{ST}}<0.05 ; \mathrm{p}>0.05\right)$.

When examining the differentiation within N-SWIO locations, $\mathrm{F}_{\mathrm{ST}}$ results highlighted a significant differentiation of most of the Seychelles locations from all other ones even if some discrepancies appear when comparing results from F-Statistics and exact test (see supplemental material Appendix D). In order to better understand the global regional structure, AMOVA was used to investigate different grouping hypotheses among all sampled locations (Table 2). According to among-group variance, the most significant model was SMC versus all N-SWIO $\left(\mathrm{F}_{\mathrm{CT}}=0.594 ; \mathrm{p}=0.014\right)$. When removing SMC from the data set, the most statistically significant model was the Amirantes group versus all other N-SWIO locations $\left(\mathrm{F}_{\mathrm{CT}}=0.094 ; \mathrm{p}=0.082\right)$, followed by the Granitic group, the Amirantes group, Farquhar and Aldabra versus all other N-SWIO locations $\left(\mathrm{F}_{\mathrm{CT}}=0.053 ; \mathrm{p}=0.012\right)$, most of the variance being explained by the within population differences (within population variance $>92 \%$; $p<0.001$ ). When taking into account the geographical location of rookeries and the genetic diversity within and among populations to identify the best $\mathrm{k}$ groups that are geographically homogenous and maximally differentiated from each other (SAMOVA), same kind of results as above approach was found $(\mathrm{k}=2$ : Amirantes, Aldabra and

Fig. 2 Neighbour-joining tree based on the mtDNA control region sequences of Chelonia mydas from the South West Indian Ocean. Newly identified haplotypes are indicated in bold font. Bootstrap values $(500$ replicates) are indicated on the branches. Three clades of haplotypes were identified, called respectively 1,2 and 3

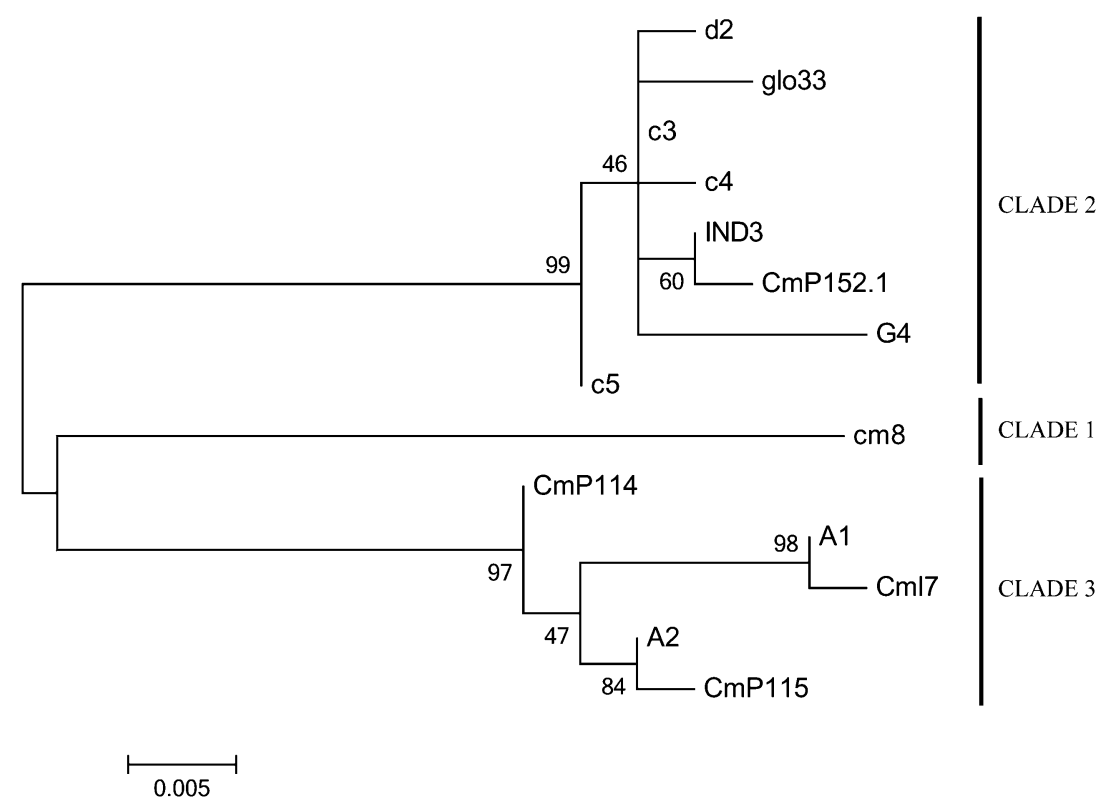


Table 2 Analysis of molecular variance (AMOVA) results for the South West Indian Ocean groups of green turtle nesting locations

\begin{tabular}{|c|c|c|c|c|c|c|}
\hline Grouping scheme & Source of variation & d.f. & Sum of square & $\%$ of variance & F statistics & $\mathrm{p}$ value \\
\hline \multirow[t]{2}{*}{ G1 = SMC locations } & AG & 1 & 542.7 & 59.0 & $0.590^{*}$ & 0.013 \\
\hline & AP/WG & 12 & 148.9 & 2.8 & $0.068 * * *$ & 0.000 \\
\hline G2 = N-SWIO locations & WP & 455 & 1632.8 & 38.2 & $0.618 * * *$ & 0.000 \\
\hline \multirow[t]{2}{*}{ G1 = Granitic, Amirantes and Farquhar groups, Aldabra } & AG & 1 & 56.3 & 6.6 & $0.066 * *$ & 0.002 \\
\hline & AP/WG & 10 & 51.9 & 1.1 & 0.012 & 0.130 \\
\hline $\mathrm{G} 2=$ other N-SWIO locations & WP & 394 & 1461.1 & 92.2 & $0.077 * * *$ & 0.002 \\
\hline \multirow[t]{2}{*}{$\mathrm{G} 1=$ Amirantes group } & AG & 1 & 46.5 & 8.9 & 0.088 & 0.084 \\
\hline & AP/WG & 10 & 61.7 & 1.9 & $0.021 *$ & 0.038 \\
\hline $\mathrm{G} 2=$ other N-SWIO locations & WP & 394 & 1461.067 & 89.2 & $0.108 * *$ & 0.002 \\
\hline
\end{tabular}

AG is the among-groups component variance; AP/WG is the among-populations/within-group component of variance; WP is the withinpopulation component of variance. The significance of permutation test $(10000$ permutations $)$ are shown for $\mathrm{p}<0.01(* *)$ and $\mathrm{p}<0.001(* * *)$ : SMC and N-SWIO: see Table 1

Farquhar and the rest of the N-SWIO; for $\mathrm{k}=3$ : Amirantes, Aldabra and Farquhar and the rest of the N-SWIO (see supplemental material Appendix E).

In order to further explore genetic structure within our dataset and in agreement with results of AMOVA and SAMOVA, we combined geographically proximal rookeries that did not have significantly different haplotype frequencies-i.e. Seychelles (including the Granitic group, the Amirantes group, Aldabra and Farquhar), East Africa (Kenya and Mozambique) and the other N-SWIO locations. Both conventional $\mathrm{F}_{\mathrm{ST}}$ statistics and the exact test results are in agreement and show strong significant differences between most locations $(p<0.001$; Table 3 ). When investigating the limit of the structure, running the same analyses but removing Aldabra from the Seychelles group, the result does not change. However, adding other close locations to the Seychelles Group (e.g. Glorieuses), we lose significance between East Africa or Seychelles and the other N-SWIO locations.

The isofrequency map of haplogroup frequencies (i.e. Clades 1, 2 and 3; Table 1) is shown on Fig. 3. This qualitative approach clearly highlights the strongest differentiation between SMC and N-SWIO. It also shows that Clade 2, dominated in frequency by haplotype $\mathrm{C} 3$, is commonly found in all SWIO regions while Clade 3 seems restricted within Clade 2 to an area situated in the northeast of the SWIO, mainly in the Seychelles. Such observation is also confirmed by the regional trend in clade frequencies by location (supplemental material Appendix E).

\section{Post-nesting migration}

Three of the four turtles tracked from St. Joseph Island exhibited limited movement between breeding and shallow foraging grounds (Fig. 4, supplemental material Appendix
B). Two turtles (\#1 and \#4) had their foraging grounds at Desroches atoll, situated only $40 \mathrm{~km}$ southeast of St. Joseph; and one turtle (\#2) stopped migrating at Platte Island located about $225 \mathrm{~km}$ east-southeast of St. Joseph. The last turtle (\#3) travelled greater distances to reach her foraging grounds which appear to be situated at Aldabra atoll, some $890 \mathrm{~km}$ southwest of St. Joseph. Turtles \#1, \#2 and \#4 each were tracked for more than 65 days at their respective foraging grounds (supplemental material Appendix B); so we are confident that these sites were the final foraging grounds of those turtles and not just stopovers in the migration. For turtle \#3, the transmission stopped when the turtle reached Aldabra. We are therefore less certain, but hypothesise that Aldabra was her final foraging ground because she reached the shallow waters of the atoll after migrating there in a nearly straight line (Fig. 4).

\section{Discussion}

The nesting sites sampled in this study encompass most of the major reproductive aggregates of green turtles in SWIO with the exception of those in Somalia, currently inaccessible due to political unrest. Beyond the mid-point of studied locations, the nearest known nesting sites for the species include those that are at least $2600 \mathrm{~km}$ away in the Central Indian Ocean (Chagos: Mortimer and Day 1999); $3100 \mathrm{~km}$ away in the Northern Indian Ocean (Yemen: NMFS and USFWS 2007; Oman: Ross and Barwani 1982); and more than $6000 \mathrm{~km}$ away in the East Indian Ocean in Australasia (Australia: Dethmers et al. 2006; Malaysia: Tisen and Bali 2002; Indonesia: Adnyana 2003). Therefore, the sampling undertaken is highly representative of the SWIO and provides results that can usefully inform management strategies of this species in the region. 
Table 3 Pairwise comparison of haplotype frequencies $\left(\mathrm{F}_{\mathrm{ST}}\right.$, below diagonal, *: $\mathrm{p}<0.05, * *: \mathrm{p}<0.01$ and ***: $\mathrm{p}<0.001$; exact $\mathrm{P}$ values, above diagonal) between sites sampled in the South West Indian Ocean and pooled into groups (locations): Europa; Juan de
Nova; East Africa: Kenya, Mozambique; Seychelles: Granitic group, Amirantes group, Aldabra and Farquhar group; Other N-SWIO: Moheli, Mayotte, Iranja, Glorieuse, Cosmoledo and Tromelin

\begin{tabular}{llllll}
\hline FST \extact test & Europa & Juan de Nova & East Africa & Others & Seychelles \\
\hline Europa & - & 0 & 0 & 0 & 0 \\
Juan de Nova & $0.3076^{* * *}$ & - & 0 & 0 & 0 \\
East Africa & $0.7294 * * *$ & $0.3079 * *$ & - & 0 & 0 \\
Others & $0.7537^{* * *}$ & $0.4360^{* * *}$ & 0.0166 & $0.0533^{* *}$ \\
Seychelles* & $0.6726^{* * *}$ & $0.3550^{* * *}$ & $0.0920^{* * *}$ & - \\
\hline
\end{tabular}

* Granitic, Amirantes and Farquhar groups, Aldabra

\section{Genetic diversity}

The newly sampled green turtle populations across the northern part of the SWIO showed similar levels of genetic diversity to those previously sampled in this region (Bourjea et al. 2007b), leading to overall similar haplotype diversity. Such levels of haplotype diversity are lower than have been found in the Atlantic ( $h=0.83$; Encalada et al. 1996) and the Pacific ( $h=0.88$; Dethmers et al. 2006) and seem to be unaffected by the small sample size. Most of the nucleotide diversity $(\pi)$ is significantly higher than has been reported from other sites in the Atlantic (e.g. Formia et al. 2006, 2007). Such patterns of variation could be attributed to different colonisation processes over time; but differences in the geographic scale between the present study $(<2500 \mathrm{~km})$ and the studies conducted in Australia and the Atlantic (both spanning $>6500 \mathrm{~km}$ ) make direct comparison unreliable.

Nevertheless, location by location, we found an important variability in haplotype diversity between nesting populations sampled in this study, that was comparable to others of similar size range in the Atlantic $(0.0<h<0.82$; Encalada et al. 1996; $0.0<h<0.73$; Formia et al. 2006), and in the Indo-Pacific $(0.07<h<0.82$; Dethmers et al. 2006). Interestingly, some of the highest values of haplotype diversity $(0.52<h<0.62)$ occurred at nesting locations that host smaller green turtle nesting populations: the Granitic group $(<200$ estimated clutches; Mortimer 1984; Bird Island and Ile du Nord Seychelles, unpublished data), Amirantes group ( $<750$ nesters, $<3500$ estimated clutches; Mortimer et al. 2011 b, J.A. Mortimer, D’Arros Research Centre, and Island Conservation Society unpublished data) and Farquhar (less than 1000 nesters; Mortimer 1984; J.A. Mortimer and Island Conservation Society unpublished data), Juan de Nova (10-30 nesters; Lauret-Stepler et al. 2010). In contrast, larger green turtle nesting populations displayed lower haplotype diversity $(0.12<\mathrm{h}<0.46)$ : Europa $(\sim 2000-11$ 000 nesters, $\sim 6000-33000$ clutches; Le Gall 1988); Aldabra ( $\sim 3000-5000$ nesters, $\sim 17,000-18,000$ clutches,
Mortimer et al. 2011b), Mayotte ( $\sim 3500$ nesters, $\sim 10,000$ clutches; Bourjea et al. 2007a), Moheli ( 4000-6000 nesters, $\sim 12,000-18,000$ clutches; Bourjea et al., submitted) and Tromelin ( 750-1000 nesters, $\sim 2100-3000$ clutches; Le Gall 1988). Such a finding was previously highlighted by Formia et al. (2006) in Atlantic populations. These authors posited the following possible explanations for higher haplotype diversity in small populations: (1) the combined effects of immigration (e.g. due to imperfect homing behaviour) and recent admixture of distinct populations would have a greater impact on small populations; or (2) the possibility that small populations are remnants of a larger ancestral population in this region. Either hypothesis might explain the patterns documented in the Seychelles and are further developed below.

\section{Revised phylogeography and population structure}

The first genetic study of green turtles in the SWIO found compelling evidence that the green turtles nesting at the rookeries of the SMC and those of the Northern SWIO (NSWIO) belong to separate stocks, with the SMC being close to the large Atlantic stock and that could be subdivided into 2 different sub-stocks, Europa and Juan de Nova (Bourjea et al. 2007b). Comparison with SMC and all new N-SWIO locations analysed in this study confirm this finding. Hypotheses explaining these results are discussed in Bourjea et al. (2007b) and will not be further developed here. However, with the new genetic data presented here, the structuring hypothesised by Bourjea et al. (2007b) for the N-SWIO now appears clearer even if it is not yet definitive. Most of the Seychelles locations (the Granitic, Amirantes and Farquhar groups) are differentiated from other N-SWIO rookeries and could belong to a separate genetic stock while the East African locations (Mozambique and Kenya) are not. However, the boundary between the Seychelles locations and the rest of the N-SWIO remains unclear and needs further investigation. 
Fig. 3 South West Indian Ocean isofrequency map constructed by inverse distance weighted interpolation method (Watson and Philips1985) and using haplogroup frequencies (i.e. Clades 1, 2 and 3; Table 2)
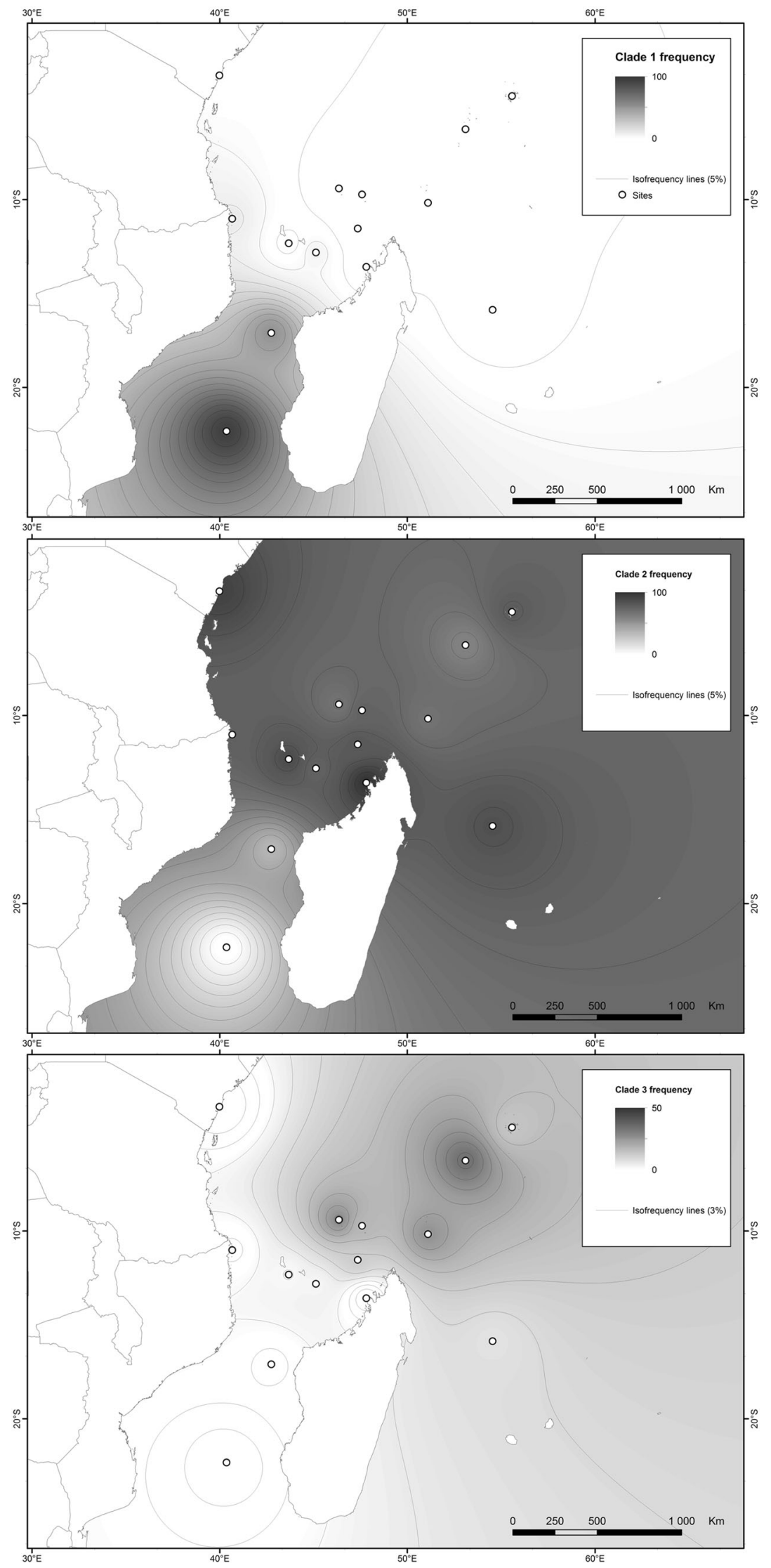
Fig. 4 Post-nesting migration paths of four nesting green turtles (\#1, \#2, \#3 and \#4) tracked from St Joseph Island, Amirantes, Seychelles. Black circle: departure site; black stars: identified foraging ground: light and dark grey lines: marine turtle tracks. See also Fig. 1 for location details

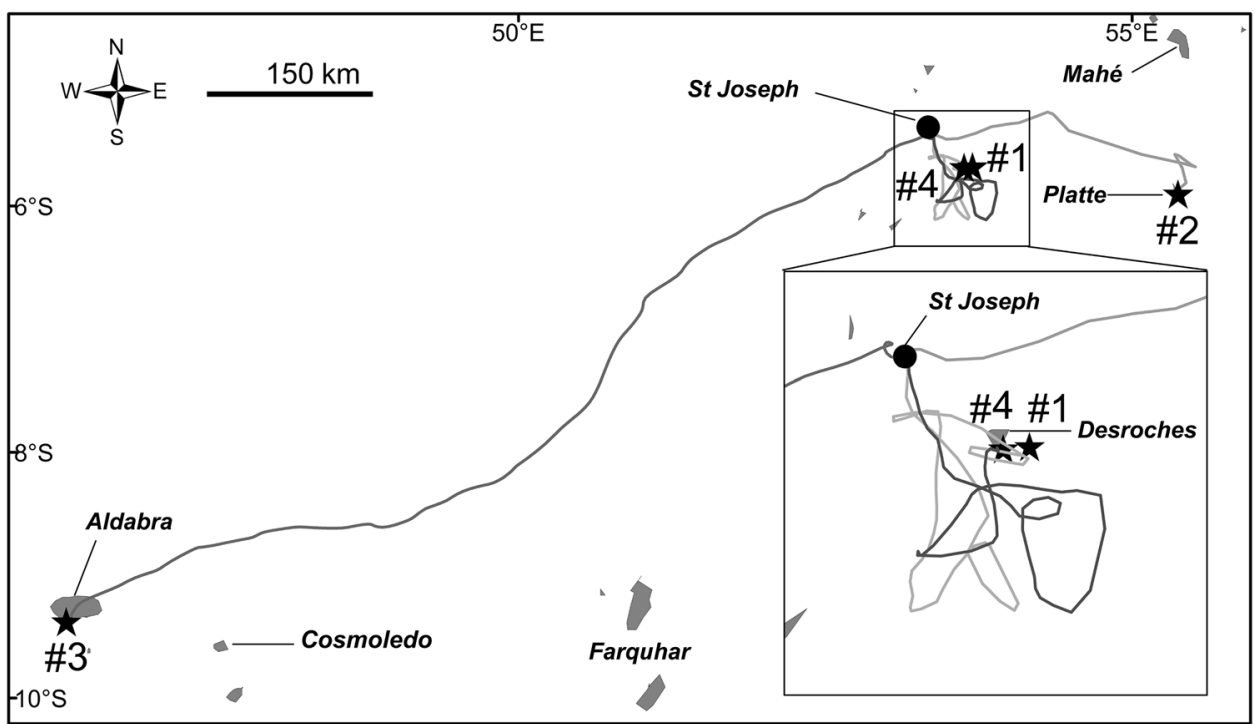

The difference between the Seychelles archipelago and the rest of the SWIO is also supported by the fact that the new haplotypes found in this study (i.e. CmP114 and CmP115) were found in Seychelles sites and are part of Clade 3 dominant in the Seychelles area. Interestingly, the two other haplotypes G4 and CmP152 also found in Seychelles, while belonging to Clade 2-the most common clade in N-SWIO sites, were never previously identified in the SWIO before. Haplotype G4 has been previously identified in the Arabian Gulf (Al-Mohanna et al. 2014) and CmP152.1 in western Java (northeast Indian Ocean, M. Jensen \& N. FitzSimmons pers. comm.).

Such genetic structure is clearly the consequence of the haplogroup (Clade) frequencies distribution. Clade 1, comprising a single haplotype CM8, is related to an Atlantic lineage (Encalada et al. 1996). It is largely dominant at Europa becoming rare further north. Clade 2 seems to be the dominant clade at all nesting sites sampled north of the Mozambique Channel while Clade 3 is centred in the Seychelles. Clade 2, dominated by the $\mathrm{C} 3$ haplotype is widely distributed across the Indian Ocean and Southeast Asia and has limited occurrence in the Pacific Ocean while Clade 3 is mostly found in the Pacific Ocean (Dethmers et al. 2006). Dethmers et al. (2006)suggested that this qualitative dispersal pattern of Clade 2 and 3 was the consequence of intervention by the Torres Strait during geological periods when it was exposed and formed a land barrier between Australia and New Guinea.

In the case of the present study, the question that remains is how to explain the high frequency of Clade 3 only in the Seychelles archipelago while it is in low frequency at all other sites in the SWIO. It is interesting to note that the foraging grounds identified for the four green turtles that nested at St. Joseph (Amirantes group) were also located in and near the Amirantes group $(\mathrm{n}=3)$ and Aldabra $(\mathrm{n}=1)$. This behaviour differs from that recorded for all other postnesting green turtles tracked in the SWIO $(n=77$; Bourjea et al. 2013; Dalleau 2013) which have been shown to use foraging grounds mainly along the east African and Malagasy coastlines and rarely within the territorial waters of Seychelles archipelago. Such a pattern of short distance migrations is similar to what was found at isolated islands such as the Cocos-Keeling Islands where nesting turtles migrate less than $40 \mathrm{~km}$ to reach their foraging ground (Whiting 2008), and support the hypothesis of limited genetic linkage between the Seychelles area and the rest of the N-SWIO. There may be linkages, however, between Seychelles and the Chagos archipelago located $1600 \mathrm{~km}$ east of Seychelles. Four of eight post-nesting green turtles satellite tracked from the Chagos settled on foraging grounds in the Amirantes group (Hays et al. 2014), while one went to the Maldives, one remained in Chagos waters, and two travelled all the way to Somalia (a distance of almost $4000 \mathrm{~km}$ ). Only limited genetic data are available for nesting green turtles in Chagos, but $44 \%$ of nine samples collected and analysed to date (Mortimer \& Broderick 1999; Bourjea et al. unpublished data) can be assigned to Clade 3, thus providing a link to Seychelles. More data on nesting green turtles satellite tracked from Seychelles archipelago and on the genetic composition of green turtles nesting in the Chagos are needed to better understand linkages between Seychelles, Chagos and the rest of the SWIO. Such a genetic link between Seychelles and Chagos has already been demonstrated for nesting and foraging hawksbill turtles (Eretmochelys imbricata) (Mortimer and Broderick 1999). Vargas et al. (2013) determined that Seychelles and Chagos together form one of nine genetic groupings of nesting hawksbills identified in the wider Indian Ocean (Sheppard et al. 2012). 


\section{Potential role of oceanography}

Several authors have already emphasised the important role that oceanic currents may play in structuring the populations of marine organisms in the western Indian Ocean, such as in the phenotypic pattern of sea birds (Le Corre 1999, 2000), the genetic structure of reef fishes (Muths et al. 2014) or pelagic fishes (Muths et al. 2013). This includes the phylogeography of marine turtles (Bourjea et al. 2007b) as green turtle offspring inhabit drift lines and oceanic gyres while carried by ocean currents during their first several years of life (Carr 1967). Moreover, recent studies combining genetic data with surface current analyses show that current patterns play an important role in determining the genetic structure of sea turtle foraging aggregations (Carreras et al. 2006; Bowen et al. 2007; Blumenthal et al. 2009; Godley et al. 2010, MonzonArgüello et al. 2010; Gaspar et al. 2012; Putman et al. 2014).

The possible impact of dominant current patterns in the SWIO on genetic structuring of oceanic populations could also have an important role in the genetic structuring of nesting green turtles observed in the N-SWIO. This region is characterized by the westward flowing South Equatorial Current (SEC), to a large part supplied by the Indonesian Throughflow (ITF). The SEC splits at the east coast of Madagascar near $17^{\circ} \mathrm{S}$ into the Northeast and Southeast Madagascar Currents respectively NEMC and SEMC; Schott 2009). The NEMC carries water westward to the north of the Comoros, creating a large anticyclonic seasonal gyre in the Comoros Basin (Lutjeharms 2005) and part of this flows south into the Mozambique Channel, part northward as the East African Coastal Current (EACC; Schouten et al. 2003). The Seychelles Archipelago comprises hundreds of scattered islands and banks that are distributed across $7^{\circ}$ of latitude (from $3^{\circ} \mathrm{S}$ to $11^{\circ} \mathrm{S}$ ) with the dominant current system being the SEC and the South Equatorial Counter Current (SECC) supplied by the EACC (Piton and Magnier 1976; Schouten et al. 2003). These currents are present year round, creating a divergence zone with boundaries varying in latitudinal width between $6^{\circ}$ and $7^{\circ}$ in austral summer to $9^{\circ}-10^{\circ}$ in winter (Piton and Magnier 1976). Jaquemet et al. (2007) suggested that this divergence zone explained differences in food availability and nesting seasonality of the sooty stern (Sterna fuscata) on the Glorieuses Islands south of the South equatorial divergence, and on Cosmoledo located on the edge of the divergence.

The ITF current is known to transport and disperse coral larvae (Knittweis et al. 2009) and therefore probably fish larvae from the Pacific to the Indian Ocean. It follows that the high frequency of Clade 3 in Seychelles might be the consequence of a flow of dominant Clade 3 hatchlings and young juveniles that hatched in the western part of Australia (e.g. Dethmers et al. 2006), Southeast Asia (e.g. in Malaysia; Tisen and Bali 2002; and in Indonesia; Adnyana 2003). All such individuals might be derived from colonial nesters that failed to return to their natal beaches to nest, especially during the important environment perturbations induced by the successive exposures of the Sunda Shelf (Voris 2000). Populations in the Seychelles archipelago that exhibit higher levels of diversity and a high frequency of Clade 3 could be attributed to a combination of imperfect or frustrated homing behaviour and a recent admixture of different stocks.

\section{Implications for management}

The problem with using short mtDNA sequences (e.g. $385 \mathrm{bp}$ ) is the danger that populations are lumped incorrectly due to a lack of significance in pairwise tests, resulting in a failure to detect existing population differentiation and to identify appropriate units of conservation (Taylor and Dizon 1999). When haplotypes overlap between nesting populations and their frequencies are similar, population differentiation may not be detected because of Type II error (Leroux et al. 2012). It follows that the use of longer DNA fragments from the maternally inherited hypervariable mtDNA control region (AbreuGrobois et al. 2006, Dutton et al. 2014a) or sequences outside established control regions (Shamblin et al. 2012) are promising approaches for detecting variation and improving finer scale stock structure analysis that should be used preferentially in the future. It is clear that higher resolution markers would offer greater power to assess stock composition and to detect patterns of movement in the green turtle. Microsatellites (e.g. Dutton et al. 2013) or single-nucleotide polymorphisms (e.g. Roden et al. 2013), for example, exhibit high levels of length mutation, resulting in extensive allelic variation and levels of heterozygosity (O'Connell and Wright 1997). These characteristics make them especially suitable for stock identification in species previously exhibiting low levels of detectable variation using mtDNA (see review in AbdulMuneer 2014) and would enable a better assessment of whether Juan de Nova should be considered a separate genetic stock as already suggested by Bourjea et al. (Bourjea et al. 2007a, b). Nevertheless, the present study suggests that the SWIO hosts two main genetic stocks of nesting green turtles: the SMC, that could be composed of two sub-stocks (a) Europa and (b) Juan de Nova, and the N-SWIO composed of two sub-stocks (c) the Seychelles archipelago - SEY; and (d) the remaining N-SWIO rookeries. Due to the low number of green turtles nesting in Juan de Nova $(<150$ tracks per year, Lauret-Stepler et al. 2010) and the fact that this isolated island is suspected to be 
a discrete genetic stock, this island has to be considered as a priority site for the conservation of nesting green turtles in this region.

Other green turtle nesting sites of critical concern for conservation are those in the Granitic and Amirantes islands of Seychelles which have suffered and continue to suffer intense depredation due to their proximity to human population centres ( $>99 \%$ of people in the Seychelles live in the Granitic Islands). Although additional investigation using other markers with enhanced sample size would be useful, we currently consider green turtles from the Granitic and Amirantes groups to be within the same genetic stock, Aldabra and Cosmoledo being a possible mixing area between SEY and the remaining large $\mathrm{N}-\mathrm{SWIO}$ stock; but what mixing may occur between these sites may not offset the current loss of turtles from the Granitic and Amirantes groups to human exploitation.

The remaining N-SWIO stock spans an unusually large geographic area, $2700 \mathrm{~km}$ from Kenya to Tromelin. In contrast, the previously most widely distributed and described genetic stock was only $<1200 \mathrm{~km}$ in Micronesia (Dethmers et al. 2006). Our study demonstrates a "border effect" within the SWIO of a large stock defined by a mtDNA marker approach (and therefore a limit of this marker), with for example Tromelin being differentiated from North Mozambique (a distance of $1500 \mathrm{~km}$ straight line) and explained by the low probability of exchange within such great distances (Bowen and Karl 2007).

The results of this study can help inform effective management of this species, by contributing to the definition of MUs (Moritz 1994; Fraser and Bernatchez 2001; Wallace et al. 2010, 2011) within this region. What is still lacking, however, are studies of the genetic composition of green turtle aggregations that inhabit the extensive foraging grounds found along the east African and Malagasy coasts, on the Seychelles and Amirantes Banks as well as other shallow sites within the region. Satellite tracking studies (Dalleau 2013; KESCOM unpublished data; Hays et al. 2014) and flipper tag returns (Mortimer 2001; J.A. Mortimer and Seychelles Islands Foundation unpublished data; Kelonia/IFREMER unpublished data) clearly demonstrate that these habitats are shared by different breeding populations within the SWIO region and beyond. We consider such a study to be a priority for regional management of this important species. As suggested by Godley et al. (2010) an integrated multiple approach is needed that combines genetic analyses of foraging aggregations, with current modelling, as well as satellite tracking and isotope signatures to demonstrate linkages between foraging and breeding habitats (Zbinden et al. 2011). This will lead to an improved understanding of the connectivity and spatial distribution of green turtles and the complexity of their life history.
Acknowledgments The authors are most grateful for the financial support of this study provided by European Union (FSE and FEDER), Regional Council of La Réunion, FAO within the framework of the FAO project GCP/INT/919/JPN "Interactions between Sea Turtles and Fisheries within an Ecosystem Approach to Fisheries Management", the EU $7^{\text {th }}$ Funding Program - Capacities, Research Potential (project RUNSeaSciences) and the SWIOFP project funded by the GEF and World Bank. In Seychelles, for assistance with genetic sample collection, JAM is grateful to: R. Bresson (Bird); L. Vanherck, U. Bristol (Ile du Nord); P. Hitchins (Cousine); A. Burt, N. Dunn (Curieuse); T. Reposa, G. Canning (Fregate); C. Arnold (Aride); E. Talma (Mahé); N. Boniface, D. Bristol, W. Labrosse, C. Boyes, R. von Brandis (D’Arros \& St. Joseph); T. Jupiter (Desroches); A. Duhec, R. Jeanne, P-A. Adam, S. Balderson (Alphonse); and G. Esparon (Farquhar). In Chagos, for assistance with sample collection, JAM is grateful to: N. Esteban, N. Guzman, G. Hays, the 1996 and 2006 Chagos Expeditions, Fauna \& Flora International, the BIOT Scientific Advisory Group (SAG), and Darwin Initiative Challenge Fund grant (EIDCF008). Field assistance to attach the satellite tags at St. Joseph was provided by R. von Brandis, N. Boniface, W. Labrosse, and D. Bristol. Organizational support in Seychelles came from D'Arros Research Centre (DRC), Island Conservation Society (ICS), Islands Development Company (IDC), Save Our Seas Foundation (SOSF), Seychelles Islands Foundation (SIF), Seychelles Department of Environment; while project funding came from the GEF EMPS-J1: Turtle and Tortoise Conservation Project, and Turtle Component of the GEF-SEYMEMP Project. The turtle project in northern Mozambique was funded by the Maluane/ Cabo Delgado Biodiversity and Tourism Project, the Zoological Society of London, Tusk Trust, the European Association of Zoo and Aquaria. BJG was supported by the Darwin Initiative. Samples for Kenya collected through KESCOM, by Watamu Turtle Watch. Finally, we would like to thank Laurence Maurel for the IDW approach used in his study.

\section{References}

Abdul-Muneer PM (2014) Application of microsatellite markers in conservation genetics and fisheries management: recent advances in population structure analysis and conservation strategies. Genet Res Int. doi:10.1155/2014/691759

Abreu-Grobois FA, Horrocks JA, Formia A, Dutton PH, LeRoux R, Velez-Zuazo X et al. (2006) New mtDNA D-loop primers which work for a variety of marine turtle species may increase the resolution of mixed stock analysis. pp. 179 in M. Frick, A. Panagopoulous, A. F. Rees, K. Williams, eds. Proceedings of the 26th annual symposium on sea turtle biology, Book of Abstracts. ISTS, Island of Crete, Greece

Adnyana IBW (2003) Preliminary assessment of Berau green turtle population. Report to WWF Indonesia Turtle Program

Al-Mohanna SY, Al-Zaidan AY, George P (2014) Green turtles (Chelonia mydas) of the north-western Arabian Gulf, Kuwait: the need of conservation. Aquat Conserv 24:166-178

Alvarado Bremer JR, Stequert B, Robertson NW, Ely B (1998) Genetic evidence for inter-oceanic subdivision of bigeye tuna (Thunnus obesus) populations. Mar Biol 132:547-557

Avise JC (1998) Conservation genetics in the marine realm. J Hered 89:377-382

Blumenthal JM, Abreu-Grobois FA, Austin TJ, Broderick AC, Bruford MW, Coyne MS, Ebanks-Petrie G, Formia F, Meylan PA, Meylan AB, Godley B (2009) Turtle groups or turtle soup: dispersal patterns of hawksbill turtles in the Caribbean. Mol Ecol 18:4841-4853 
Bourjea J, Frappier J, Quillard M, Ciccione S, Roos D, Hughes G, Grizel H (2007a) Mayotte Island: another important green turtle nesting site in the south west Indian Ocean. Endang Species Res 3:273-282

Bourjea J, Lapegue S, Gagnevin L, Broderick D, Mortimer JA, Roos D, Taquet C, Grizel H (2007b) Phylogeography of the green turtle, Chelonia mydas, in the southwest Indian Ocean. Mol Ecol 16:175-186

Bourjea J, Nel R, Jiddawi NS, Koonjul MS, Bianchi G (2009) Sea turtle bycatch in the West Indian Ocean: review, recommendations and research priorities. West Ind Ocean J Mar Sci 7(2):137-150

Bourjea J, Ciccione S, Dalleau M (2013). Dynamique migratoire des tortues marines nidifiant dans les îles françaises de l'océan Indien. Rapport Scientifique et Technique Ifremer, RST-DOI/ 2013-02. http://dx.doi.org/10.13155/28050

Bourjea J, Dalleau M. Derville S, Beudard F, Marmoex C, M'soili A, Roos D, Ciccione S, Frazier $\mathrm{J}$ submitted. Seasonality and increasing nesting of green turtles at Itsamia, Mohéli, Comoros. Endang Species Res

Bowen BW, Karl SA (2007) Population genetics and phylogeography of sea turtles. Mol Ecol 16:4886-4907

Bowen BW, Grant WS, Hillis-Starr Z, Shaver DJ, Bjorndal KA, Bolten AB, Bass AL (2007) Mixed-stock analysis reveals the migration of juvenile hawksbill turtles (Eretmochelys imbricata) in the Caribbean Sea. Mol Ecol 16:49-60

Carlsson J, McDowell JR, Diaz-Jaimes P, Carlsson EL, Boles SB, Gold JR, Graves JE (2004) Microsatellite and mitochondrial DNA analyses of Atlantic bluefin tuna (Thynnus thynnus) population structure in the Mediterranean Sea. Mol Ecol 13:3345-3356

Carr AF (1967) So excellent a fishe: a natural history of sea turtles. Natural History Press, Garden City 248

Carreras C, Pont S, Maffuci F, Pascual M, Barcelo A, Bentivegna F, Cardona L, Alegre F, SanFélix M, Fernandez G, Aguilar A (2006) Genetic structuring of immature loggerhead turtles (Caretta caretta) in the Mediterranean Sea reflects water circulation patterns. Mar Biol 149:1269-1279

CLS (2014) Argos User's Manual V.1.6.3-Worldwide tracking and environmental monitoring by satellite. CLS-Argos. $66 \mathrm{pp}$

Dalleau M (2013) Ecologie spatiale des tortues marines dans le Sudouest de l'océan Indien. Apport de la géomatique et de la modélisation pour la conservation. Thèse de doctorat. Université de La Réunion. 330 pp

Dalleau M, Ciccione S, Mortimer JA, Garnier J, Benhamou S, Bourjea J (2012) Nesting phenology of marine turtles: insights from a regional comparative analysis on green turtle (Chelonia mydas). PLoS ONE 7:e46920

DeSalle R, Amato G (2004) The expansion of conservation genetics. Nat Rev Genet 5:702-712

Dethmers K, Broderick D, Moritz C, Limpus C, FitzSimmons NN (2006) The genetic structure of Australasian green turtles (Chelonia mydas): geographic scale of genetic exchange. Mol Ecol 15:3931-3946

Dupanloup I, Schneider S, Excoffier L (2002) A simulated annealing approach to define the genetic structure of populations. Mol Ecol 11(12):2571-2581

Durand J, Collet A, Chow S, Guinand B, Borsa P (2005) Nuclear and mitochondrial DNA markers indicate unidirectional gene flow of Indo-Pacific to Atlantic bigeye tuna (Thunnus obesus) populations, and their admixture off southern Africa. Mar Biol 147:313-322

Dutton PH (1996) Methods for collection and preservation of samples for sea turtle genetic studies. In: Bowen BW, Witzell WN (ed) Proceedings of the International Symposium on Sea Turtle Conservation Genetics. NOAA Technical Memorandum, NMFSSEFSC-396 Miami, pp. 17-24

Dutton PH, Balazs GH, Leroux RA, Murakawa SKK, Zarate P, Martinez LS (2008) Composition of Hawaiian green turtle foraging aggregations: mtDNA evidence for a distinct regional population. Endang Species Res 5:37-44

Dutton PH, Roden SE, Stewart KR, Lacasella E, Tiwari M, Formia A, Thomé JC, Livingstone SR, Eckert S, Chacon-Chaverri D, Rivalan P, Allman P (2013) Population stock structure of leatherback turtles (Dermochelys coriacea) in the Atlantic revealed using mtDNA and microsatellite markers. Conserv Genet 14:625-636

Dutton PH, Jensen MP, Frey A, LaCasella E, Balazs GH, Zarate P, Chassin-Noria O, Sarti-Martinez AL, Velez E (2014a) Population structure and phylogeography reveal pathways of colonization by a migratory marine reptile (Chelonia mydas) in the central and eastern Pacific. Ecol Evol 4(22):4317-4331

Dutton PH, Jensen MP, Frutchey K, Frey A, LaCasella E, Balazs GH, Cruce J, Tagarino A, Farman R, Tatarata M (2014b) Genetic stock structure of green turtle (Chelonia mydas) nesting populations across the Pacific Islands. Pac Sci 68(4):451-464

Ely B, Vinas J, Alvarado Bremer JR, Black D, Lucas L, Covello K, Labrie AV, Thelen E (2005) Consequences of the historical demography on the global population structure of two highly migratory cosmopolitan marine fishes: the yellowfin tuna (Thunnus albacares) and the skipjack tuna (Katsuwonus pelamis). Evol Biol 5:1-19

Encalada SE, Lahanas PN, Bjorndal KA, Bolten AB, Miyamoto MM, Bowen BW (1996) Phylogeography and population structure of the green turtle (Chelonia mydas) in the Atlantic Ocean and Mediterranean Sea: a mitochondrial DNA control region sequence assessment. Mol Ecol 5:473-484

Excoffier L, Lischer HEL (2010) Arlequin ver 3.5: a new series of programs to perform population genetics analyses under Linux and Windows. Mol Ecol Resour 10:564-567

Excoffier L, Smouse PE, Quattro JM (1992) Analysis of molecular variance inferred from metric distances among DNA haplotypes-application to human mitochondrial DNA restriction data. Genetics 131:479-491

Formia A, Godley BJ, Dontaine J-F, Bruford MW (2006) Mitochondrial DNA diversity and phylogeography of endangered green turtle (Chelonia mydas) populations in Africa. Conserv Genet 7:353-369

Formia A, Broderick AC, Glen F, Godley BJ, Hays GC, Bruford MW (2007) Genetic composition of the Ascension Island green turtle rookery based on mitochondrial DNA: implications for sampling and diversity. Endang Species Res 3:145-158

Frazier J (1975) Marine turtles of the western Indian Ocean. Oryx 13:164-175. doi:10.1017/S0030605300013387

Frazier J (1984) Marine turtles in the Seychelles and adjacent territories. In: Stoddardt DR (ed) Biogeography and ecology of the Seychelles Islands. Dr W. Junk Publishers, The Netherlands, pp 417-468

Garnier J, Hill N, Guissamulo A, Silva I, Debney A, Godley B (2012) Status and community-based conservation of marine turtles in the northern Querimbas Islands (Mozambique). Oryx 46(3):359-367

Gaspar P, Benson SR, Dutton PH, Reveillere A, Jacob G, Meetoo C, Dehecq A, Fossette S (2012) Oceanic dispersal of juvenile leatherback turtles: going beyond passive drift modeling. Mar Ecol Prog Ser 457:265-284

Godley BJ, Barbosa C, Bruford M, Broderick AC, Catry P, Coyne MS, Formia A, Hays GC, Witt MJ (2010) Unravelling migratory connectivity in marine turtles using multiple methods. J Appl Ecol 47:769-778

Hamabata T, Kamezaki N, Hikida T (2014) Genetic structure of green turtle (Chelonia mydas) peripheral populations nesting in the northwestern Pacific rookeries: evidence for northern refugia and postglacial colonization. Mar Biol 161:495-507

Hawkes LA, Tomás J, Revuelta O, León YM, Blumenthal JM, Broderick AC, Fish M, Raga JA, Witt MJ, Godley BJ (2012) 
Migratory patterns in hawksbill turtles described by satellite tracking. Mar Ecol Prog Ser 461:223-232

Hays GC, Mortimer JA, Ierodiaconou D, Esteban N (2014) Use of long-distance migration patterns of an endangered species to inform conservation planning for the world's largest marine protected area. Conserv Biol. 145 pp. doi:10.1111/cobi.12325

Henley S (1981) Nonparametric geostatistics. Wiley, New York

Howell KM, Mbindo C (1996) The status of sea turtle conservation in Tanzania. In: Humphrey SL, Salm RV (ed), Status of Sea Turtle Conservation in the Western Indian Ocean. UNEP Regional Seas Reports and Studies. IUCN/UNEP, Nairobi, Kenya, pp. 73-80

Hughes GR (1973) The sea turtles of south east Africa. Doctoral thesis. University of Natal, Durban

Hughes GR (1996) Nesting of leatherback turtle (Dermochelys coriacea) in Tongaland, KwaZulu- Natal, South Africa, 1963-1995. Chelonian Conserv Biol 2:153-158

Jaquemet S, Lecorre M, Quartly GD (2007) Ocean control of the breeding regime of the sooty tern in the southwest Indian Ocean. Deep-Sea Res I 54:130-142

Kimura M (1980) A simple method for estimating evolutionary rates of base substitutions through comparative studies of nucleotide sequences. J Mol Evol 16:111-120

Knittweis L, Kraemer WE, Timm J, Kochzius M (2009) Genetic structure of Heliofungia actiniformis (Scleractinia: Fungiidae) populations in the Indo-Malay Archipelago: implications for live coral trade management efforts. Conserv Genet 10:241-249

Kumar S, Tamura K, Jakobsen I, Nei M (2001) MEGA2: molecular evolutionary genetics analysis software. Bioinformatics 17:1244-1245

Lauret-Stepler M, Bourjea J, Roos D, Pelletier D, Ryan PG, Ciccione S, Grizel H (2007) Reproductive seasonality and trend of Chelonia mydas in the SW Indian Ocean: a $20 \mathrm{yr}$ study based on tracks counts. Endang Species Res 3:217-227

Lauret-Stepler M, Ciccione S, Bourjea J (2010) Monitoring of marine turtles reproductive activities in Juan de Nova, Eparses Islands, south western Indian Ocean, based on tracks counts and width. Indian Ocean Mar Turt Newsl 11:18-24

Le Corre M (1999) Plumage polymorphism of red-footed boobies (Sula sula) in the western Indian Ocean: an indicator of biogeographic isolation. J Zool Soc London 249:411-415

Le Corre M (2000) Taxonomic affinities of Audubon's shearwater from Europa Island. Condor 102:187-190

Le Gall JY (1988) Biologie et évaluation des populations de tortues vertes Chelonia mydas des atolls Tromelin et Europa (Océan Indien S.O.). Mésogée 48:33-42

Le Gall JY, Bosc P, Château D, Taquet M (1986) Estimation du nombre de tortues vertes femelles adultes Chelonia mydas par saison de ponte a Tromelin et Europa (Océan Indien) (1973-1985). Océanographie Tropicale 21:3-22

Lee PLM (2008) Molecular ecology of marine turtles: new approaches and future directions. J Exp Mar Biol Ecol 356:25-42

LeRoux RA, Dutton PH, Abreu-Grobois FA, Lagueux JC, Campbell CL, Delcrois E, Chevalier J, Horrocks JA, Hillis-Starr A, Troeng S, Harrison E, Stapleton S (2012) Re-examination of population structure and phylogeography of hawksbill turtles in the Wider Caribbean using longer mtDNA sequences. J Hered 103:806-820

Lutjeharms JRE (2005) The coastal oceans of south-eastern Africa. In: Robinson AR, Brink K (eds) The sea. Chicago University Press, Chicago, pp 781-832

Malakoff D (1997) Extinction of the high seas. Science 277(5325): 486-488

Meylan AB, Bowen BW, Avise JC (1990) A genetic test of the natal homing versus social facilitation models for green turtle migration. Science 248:724-727

Monzon-Argüello C, Lopez-Jurado LF, Rico C, Marco A, Lopez P, Hays GC, Lee PLM (2010) Evidence from genetic and
Lagrangian drifter data for transatlantic transport of small juvenile green turtles. J Biogeogr 37:1752-1766

Moritz C (1994) Applications of mitochondrial DNA analysis in conservation: a critical review. Mol Ecol 3:401-411

Mortimer JA (1984) Marine Turtles in the Republic of Seychelles: Status and Management. IUCN Conservation Library, Gland. 80 pp

Mortimer JA (1985) Recovery of green turtles on Aldabra. Oryx 19:146-150

Mortimer JA (1988) Green turtle nesting at Aldabra Atoll-population estimates and trends. Bull Biol Soc Wash 8:116-128

Mortimer JA (2001) Turtle Talk: international migrations of sea turtles tagged at Aldabra. Seychelles Isl Found Newsl 7:1-3

Mortimer JA, Broderick D (1999) Population genetic structure and developmental migrations of sea turtles in the Chagos Archipelago and adjacent regions inferred from mtDNA sequence variation. In: Sheppard CRC, Seaward MRD (eds) Ecology of the Chagos Archipelago. Linnean Society of London (Occasional Publication 2), Westbury Publishing, Otley, UK, pp 185-194

Mortimer JA, Day M (1999) Sea turtle populations and habitats in the Chagos Archipelago. In: Sheppard CRC, Seaward MRD (eds) Ecology of the Chagos Archipelago. Linnean Society of London (Occasional Publication 2), Westbury Publishing, Otley, UK, pp. 159-172

Mortimer JA, Camille J-C, Boniface N (2011a) Seasonality and status of nesting hawksbill (Eretmochelys imbricata) and green turtles (Chelonia mydas) at D'Arros Island, Amirantes Group. Seychelles. Chelonian Conserv Biol 10(1):26-33

Mortimer JA, von Brandis RG, Liljevik A, Chapman R, Collie J (2011b) Fall and rise of nesting green turtles (Chelonian mydas) at Aldabra Atoll, Seychelles: positive response to four decades of protection (1968-2008). Chelonian Conserv Biol 10(2):165-176

Muths D, Le Couls S, Evano H, Grewe P, Bourjea J (2013) Multigenetic marker approach and spatio-temporal analysis suggest there is a single panmictic population of swordfish Xiphias gladius in the Indian Ocean. PLoS One 8(5):e63558. doi:10. 1371/journal.pone. 0063558

Muths D, Tessier E, Bourjea J (2014) Genetic structure of the reef grouper Epinephelus merra in the west Indian Ocean appears congruent with biogeographic and oceanographic boundaries. Mar Ecol. doi:10.1111/maec.12153,1-15

NMFS, USFWS (National Marine Fisheries Service and United States Fish and Wildlife Service) (2007) Green sea turtle (Chelonia mydas) 5-year review: summary and evaluation. National Marine Fisheries Service, Silver Spring, Maryland, and U.S. Fish and Wildlife Service, Jacksonville, Florida, 105 pp

Norman JA, Moritz C, Limpus C (1994) Mitochondrial DNA control region polymorphisms: genetic markers for ecological studies of marine turtles. Mol Ecol 3:363-373

O'Connell M, Wright JM (1997) Microsatellite DNA in fishes. Rev Fish Biol Fish 7:331-363

Okemwa GM, Nzuki S, Mueni EM (2004) The status and conservation of sea turtles in Kenya. Mar Turt Newsl 105:1-6

Palumbi SR (2003) Population genetics, demographic connectivity and the design of marine protected areas. Ecol Appl 13:146-158

Parsons JJ (1962) The green turtle and man. University of Florida Press, Gainesville

Piton B, Magnier Y (1976) Les conditions favorables de la présence des thons de surface dans les parages de Madagascar. ORSTOM 47:293-309

Putman NF, Abreu-Grobois FA, Broderick AC, Ciofi C, Formia A, Godley BJ, Stroud S, Pelembe T, Verley P, Williams N (2014) Numerical dispersal simulations and genetics help explain the origin of hawksbill sea turtles in Ascension Island. J Exp Mar Biol Ecol 450:98-108

Raymond M, Rousset F (1994) An exact test for population differentiation. Evolution 49(6):1280-1283 
Raymond M, Rousset F (1995) GENEPOP (version 1. 2): a population genetics software for exact tests and ecumenicism. J Hered 86:248-249

Read TC, Wantiez L, Werry JM, Farman R, Petro G et al (2014) Migrations of green turtles (Chelonia mydas) between nesting and foraging grounds across the Coral Sea. PLoS One 9(6):e100083. doi:10.1371/journal.pone. 0100083

Reece JS, Castoe TA, Parkinson CL (2005) Historical perspectives on population genetics and conservation of three marine turtle species. Conserv Genet 6:235-251

Roden SE, Morin PA, Frey A, Balazs GH, Zarate P, Cheng I-J et al (2013) Green turtle population structure in the Pacific: new insights from single nucleotide polymorphisms and microsatellites. Endanger Species Res 20:227-234

Ross JP, Barwani MA (1982) Review of sea turtles in the Arabian area. In: Bjorndal KA (ed) Biology and conservation of sea turtles. Smithsonian Institution Press, Washington, DC, pp 373-383

Schott FA, Xie S-P, McCreary JP (2009) Indian Ocean circulation and climate variability. Rev Geophys 47:RG1002

Schouten MW, Ruijter WPM, Leeuwen PJV, Ridderinkhof H (2003) Eddies and variability in the Mozambique Channel. Deep-Sea Res II 50:1987-2003

Schwartz MK, Luikart G, Waples RS (2007) Genetic monitoring as a promising tool for conservation and management. Trends Ecol Evol 22:25-33

Shamblin BM, Bjorndal KA, Bolten AB, Hillis-Starr ZM, Lundgren A, Naro-Maciel E, Nairn CJ (2012) Mitogenomic sequences better resolve stock structure of southern Greater Caribbean green turtle rookeries. Mol Ecol 21:2330-2340

Sheppard CRC, Ateweberhan M, Bowen BW, Carr P, Chen CA et al (2012) Reefs and islands of the Chagos Archipelago, Indian Ocean: why it is the world's largest no-take marine protected area. Aquat Conserv 22:232-261

Taylor BL, Dizon AE (1999) First policy then science: why a management unit based solely on genetic criteria cannot work. Mol Ecol 8:S11-S16

Tisen OB, Bali J (2002) Current status of marine turtle conservation programmes in Sarawak, Malaysia. In: Witzell WN (ed)
Proceeding of the Twentieth Annual Symposium on Sea Turtle Biology and Conservation. Orlando, Florida, USA, pp 12-14

Vargas SM, Jensen MP, Mobaraki A, Santos FR, Broderick D, Mortimer JA, Limpus C, Whiting S, FitzSimmons N (2013) Phylogeography of the hawksbill turtle (Eretmochelys imbricata) from the Indo-Pacific Region. In: Proceedings of the 30th Annual Symposium on Sea Turtle Biology and Conservation. Blumenthal, J., Panagopouou, A., Rees, A.F. (compilers). NOAA Technical Memorandum NMFS-SEFSC-640: 177, p. 155

Voris HK (2000) Maps of Pleistocene sea levels in Southeast Asia: shorelines, river systems and time durations. J Biogeogr 27: 1153-1167

Wallace BP, DiMatteo AD, Hurley BJ, Finkbeiner ME, Bolten AB et al (2010) Regional management units for marine turtles: a novel framework for prioritizing conservation and research across multiple scales. PLoS One 5(12):e15465. doi:10.1371/ journal.pone. 0015465

Wallace BP, DiMatteo AD, Bolten AB, Chaloupka MY, Hutchinson BJ et al (2011) Global Conservation Priorities for Marine Turtles. PLoS One 6(9):e24510. doi:10.1371/journal.pone.002 4510

Ward RD (2000) Genetics in fisheries management. Hydrobiologia 420:191-201

Watson DF, Philip GM (1985) A refinement of inverse distance weighted interpolation. Geoprocessing 2:315-327

Weir BS, Cockerham CC (1984) Estimating F statistics for the analysis of population structure. Evolution 38:1358-1370

Whiting SD, Murray W, Macrae I, Thorn R, Chongkin M, Koch AU (2008) Non-migratory breeding by isolated green sea turtles (Chelonia mydas) in the Indian Ocean: biological and conservation implications. Naturwissenschaften 95:355-360

Wright S (1951) The genetical structure of population. Ann Eugen 15:323-354

Zbinden JA, Bearhop S, Bradshaw P, Gill B, Margaritoulis B, Newton J, Godley BJ (2011) Migratory dichotomy and associated phenotypic variation in marine turtles revealed by satellite tracking and stable isotope analysis. Mar Ecol Prog Ser 421:0291-0302 